\title{
Evaluation of the Creative Skills of the Classroom Teacher Candidates' Taking Visual Arts Training Course
}

\author{
Sibel Adar Cömert \\ Department of Art Teaching, Faculty of Education, Omer Halisdemir University, Turkey
}

Copyright@2019 by authors, all rights reserved. Authors agree that this article remains permanently open access under the terms of the Creative Commons Attribution License 4.0 International License

\begin{abstract}
This study aims to measure the skills of classroom teacher candidates' in transforming their creativity into artistic design. Descriptive analysis technique, which is one of the qualitative research techniques, is used and document review method is applied in the study. The research consists of data obtained as a result of an observation conducted by the researcher during a total of 78 course hours throughout one term with the 4th year students of Classroom Teaching Faculty of Niğde Ömer Halis Demir University. As a result, it is observed that at the beginning of the study, students were biased on their skills and felt unsuccessful in art. As students focus more on teacher appointment exams, they have always wanted to pass exams without an effort and take grade in a very short span of time. It has been observed that students, in general, don't have any attempt to be creative.
\end{abstract}

Keywords Visual Arts Education, Painting Course, Classroom Teacher Candidates

\section{Introduction}

Since the existence of the human being, people, consciously or unconsciously, have become a part of art. Art is essential for our lives. It is a comprehensive concept that makes its creator and consumer happier (Hicks,2004 Aktaran Mercin, [1]. Art is a spiritual activity for people to help them express their emotions and feelings effectively in an individual manner with the help of elements such as line, color, style, sound, word and the rhythm (Aytaç, 1981 aktaran Artut, [2]. Since the beginning of the written history of humankind, philosophers and artists have perceived art differently. Plato defined art as a copy of a copy and the imitation of an image and nature (mimesis) (Read, [3].

Art is an expression: Art can have an important role in transmitting feelings, opinions, images and values through symbols Özsoy, [4]. According to Gombrich [5], there really is no such thing as "art", there are only artists, there is a great variety of activities through ages from primitive people who created cave paintings to today's poster designers.

An individual is born with emotions like intuition and curiosity as a necessity of its nature he needs to express his thoughts. Ayaydın [6], Art education has an important role in contributing to social, physical and psychological growth of an individual. According to Adar [7], Art education primarily helps children's physical and mental development and therefore it helps those of adults'. It provides an opportunity to reveal students' real feelings and express them more clearly Tansuğ [8].

In the most general and simplest sense art is defined as an expression of original creativity and imagination senses of an individual. According to Kehnemuyi [9], as a form of art such as ceramic, painting, sculpture, design, photography, tile-making and architecture visual arts produce only visual products. Painting as an art form is the most known and common one. Painting course in the educational program of the Ministry of Education in previous years used to be limited to just painting Çağlarca [10]. In today's curriculum the content of the painting course is expanded and the name of course has changed to Visual Arts Gökaydın [11].

Drawing, which is a form of visual arts, is the most ordinary, effective and simplest way to reflect an individual's inner feelings and emotions, views and world of imagination. Drawing as a nonverbal means of communication, has an important role in childhood. Visual arts course gives an opportunity to children to show their creativity, motivates and makes them relaxed. Said course is received as 2 course hours (40'+40') in the first level of the primary school. 4th grade classroom teacher candidates have also received visual arts teaching course 3 hours a week ( 1 theoterical+2 practical) in order to recognize the 
functions of visual arts education, to determine the development level of students according to stages of development displayed by graphics, to understand the theme of drawings of children, to observe the differences in visual, auditory and tactual perceptions and ensure the development of creativity through designing painting and graphics in accordance with the program, textile design, architectural design and conventional design, painting and drawing.

In this research, artistic skills of 4th grade students of classroom teaching department were evaluated in the visual arts education course. Students' point of views, interests in the course and their adaptation to the lesson have also been considered.

\subsection{Art Elements}

'Art elements are the first building blocks considered in all kinds of visual design. The artistic value of an art work is defined by the used of art elements and design principles in the most ideal way' (Ayaydın,[6] 2009: 111). Art elements can be listed as line, dot, color, texture and form.

This study is based on the visual arts curriculum used in the first level of general education schools. The most frequently encountered art elements in the program, which are line, color, dot and texture, were taken into account, and simple, different and visually rich art works were performed by the students. In this process, the students were able to do their work without being bored and have enjoyed quite a lot.

The line is one of the most important elements in painting art. It plays a major role in the formation of shape and composition on the surface. According to Gökaydin[11] (1998: 25), the line is a simplification event. It is the simplest means of expression of the artist's most complex emotions. The line is the first tool we use in describing our childhood intuition.

The line is able to express all the feelings and objects without the need for any other elements in terms of expression options. (Karayağmurlar) [12]

The color element is the best tool for narration, because its powerful influence affects our emotions directly in a short time (Ocvirk et.al. 1960, cited in Ayaydın, 2009: 114). Thus, it is the main element in the establishment of the painting. Due to the depth effect of color in people, artists feature color perspective.

In plastic arts, the appearance and characteristics of the coat covering the surface of the assets used as models is called texture. The surface of each substance in nature is covered with a texture type. Getting to know the texture of the surface of the goods well, strengthens our observations and adds spirit and vitality to the work we will do (Kılıçkan,[13]. According to Gökaydın (2002: 89), texture is a situation where elements of an order come together to lose their personalities and make a total impact.

Although they are not noticeable in the formal elements, dots present the possibilities of expression according to the intensity in their collateral standing. In all the paintings, as they stand between lines and spots, they enrich the visualization. We can also recall that paints are used as dots in order to obtain light mixtures instead of dye mixtures in the paintings of .Puvantilists (Karayağmurlar, 2002: 12).

\section{Materials and Methods}

This section includes the information on the pattern of the research, working group, collection of data, duration of data collection and data analysis.

\subsection{Importance of the Study}

The research is important in terms of measuring the capability of the students to transform their knowledge and skills obtained during the course into artistic design.

\subsection{Research Model}

This is a descriptive research that focuses on the levels of the creativity of the classroom teacher candidates in painting skills by taking into consideration the elements of art. Descriptive research is a research in which obtained data is summarized and interpreted according to previous themes. Data in question can be classified according to the themes revealed by the research questions and they can also be submitted by taking into consideration questions or dimensions used in the interviews and observation processes (Yıldırım and Şimşek [14]. In the research, 'the Document Analysis' method, which is one of the qualitative research techniques, was used. The 'Document Analysis' is a method that comprises of the analysis of written materials containing information on case or cases aimed to be searched Karasar[15]. Such documents can be used as data source in education research: course books, curriculum directives, internal and external correspondence, students' records, home works and exams, course and unit plans, teacher files, official documents related to education etc. (Bogdan and Biklen 1992; Goetz and Lecompte,[14] 1984). The research is limited to evaluation patterns such as 'Texture- Colour-Line-Dot'.

\subsection{Research Groups}

This research was conducted with 4th grade (last year) Classroom Teaching Department Students of Faculty of Education of Niğde Ömer Halis Demir University during Fall Semester in 2016-2017 academic year, 3 hours (course)a week $\left(45^{\prime}+45^{\prime}+45^{\prime}\right), 13$ weeks in total. Consisting of students from 2 classes, the number of the students in A class was 69 and those of B Class was 65. Application study was conducted with 134 students for 84 course hours under the observation of the researcher. 
Table 1. Quantity of Students participated in the Research, Name of the Practice School and the Class

\begin{tabular}{|c|c|c|c|}
\hline Name of the Practice School and the Class & M & $\mathrm{F}$ & Total \\
\hline $\begin{array}{l}\text { 4th grade Students of Classroom Teaching } \\
\text { Department of Faculty of Education of Niğde } \\
\text { Ömer Halis Demir University, Class A }\end{array}$ & 24 & 45 & 69 \\
\hline $\begin{array}{l}\text { 4th grade Students of Classroom Teaching } \\
\text { Department of Faculty of Education of Niğde } \\
\text { Ömer Halis Demir University, Class B }\end{array}$ & 17 & 48 & 65 \\
\hline
\end{tabular}

\subsection{Research Documents}

In the research, data have been collected by the researcher from 4th grade visual arts education course of the classroom teaching department. With the help of data collected, the observations and evaluations of the researcher have been concluded. The researcher has also used his visual arts teaching experiences performed in the first and second level of primary school for 12 years. The research is limited to some artistic design elements such as line, color, texture and dot. In this application, the levels of creativity of the classroom teacher candidates in visual arts education have been evaluated.

\subsection{Data Collection Tools}

Artworks have been evaluated according to the Artistic Elements like Color, Texture, Line and Dot. A sample performance evaluation table for the 'LINE' is as follows. Application studies created for each artistic elements have been prepared for each student to determine their design skills and each column in the sample table below is separated as yes or no to indicate their preference by putting ' $\mathrm{X}$ ' in the right place. 4 different evaluation tables have been prepared for each element, Line, Color, Texture and Dot. Results have been summarized and interpreted.

Table 2. Performance Evaluation Table Sample ( Line)

\begin{tabular}{|l|c|c|}
\hline \multirow{2}{*}{\multicolumn{1}{|c|}{ LINE }} & \multicolumn{2}{c|}{$\begin{array}{c}\text { Name of the } \\
\text { Student }\end{array}$} \\
\cline { 2 - 3 } & Yes & No \\
\hline Does your artwork have a proportion/ scale? & $\mathrm{X}$ & \\
\hline Does your artwork have direction & & $\mathrm{X}$ \\
\hline Does your artwork have rhythm? & $\mathrm{X}$ & \\
\hline Does your artwork have space? & $\mathrm{X}$ & \\
\hline Does your artwork have light/shadow? & & $\mathrm{X}$ \\
\hline Does your artwork have harmony & & $\mathrm{X}$ \\
\hline Does your artwork have contrast & & $\mathrm{X}$ \\
\hline Does your artwork have dominance? & $\mathrm{X}$ & \\
\hline Does your artwork have balance? & $\mathrm{X}$ & \\
\hline Does your artwork have unity? & $\mathrm{X}$ & \\
\hline
\end{tabular}

\section{Findings}

Findings show that students don't have self- confidence at the beginning of the study and they said that they would be classroom teachers, not art teachers and they were untalented in art and incapable of drawing a picture, and had such a belief that 'if we had an ability to draw, we would be an art teacher. Fort his reasons, most of the students don't have any concern about being creative and to put an effort to create an artistic work. Instead of using sources from the internet to get an idea for their studies, they have preferred to finish their works by using exactly the same work and get good marks without an effort Although they have more fine motor skills than any other the primary school students, and advanced drawing and creative abilities, they have produced ordinary and classical works. A few of students have created detailed and unique designs. It has been observed that girls were more creative, patient than boys and they were able to design more detailed works. Students have focused more on PPSE (KPSS) exam due to appointment and they spent most of their time studying, taking tests and they were not able to study drawing due to lack of time. They have persisted on passing their exams with high grades. Therefore such attitude prevented them from spending long hours for drawing and they are not concerned any more to create new artworks.

Table 3. The ability of students to apply design skills

\begin{tabular}{|l|c|c|c|c|}
\hline \multirow{2}{*}{\multicolumn{1}{|c|}{ LINE }} & \multicolumn{2}{|c|}{ Class A } & \multicolumn{2}{c|}{ Class B } \\
\cline { 2 - 5 } & Yes & No & Yes & No \\
\hline $\begin{array}{l}\text { Does your artwork have proportion/ } \\
\text { scale? }\end{array}$ & 55 & 14 & 48 & 17 \\
\hline Does your artwork have direction? & 42 & 27 & 45 & 20 \\
\hline Does your artwork have rhythm? & 15 & 54 & 24 & 41 \\
\hline Does your artwork have space? & 18 & 51 & 19 & 46 \\
\hline Does your artwork have light/shadow? & 5 & 64 & 5 & 60 \\
\hline Does your artwork have harmony? & 40 & 29 & 45 & 20 \\
\hline Does your artwork have contrast? & 8 & 61 & 4 & 61 \\
\hline Does your artwork have dominance? & 32 & 37 & 48 & 17 \\
\hline Does your artwork have balance? & 50 & 19 & 51 & 14 \\
\hline Does your artwork have unity? & 54 & 15 & 55 & 10 \\
\hline
\end{tabular}

According to observations, most of the students were able to arrange a successful ratio and proportion element in composition, they succeeded in composing harmony, movement , balance and unity . Almost all artworks created by the students were lacking movement, light, shadow and contrast elements

\section{Discussion and Conclusions}

This study is based on the visual arts curriculum used in the first level of general education schools. The most frequently encountered art elements in the program, which are line, color, dot and texture, were taken into account, and simple, different and visually rich art works were 
performed by the students. In this process, the students were able to do their work without being bored and have enjoyed quite a lot.

Studies aim to measure the ability of primary school students in designs in terms of the art elements such as line, color, texture and dots. Lack of self-confidence and biased attitudes have prevented students from being successful. However, students themselves were confused with the results. Their opinions have changed when they see their friends' results and they feel encouraged by the results.

As Students see assignment exam as a challenge to be a teacher they tend to concentrate more on this exam. Such courses outside the exam are considered by the students as loss of time. They don't want to spend time over such courses. They can have good results if they stop worrying about these exams. Moreover, getting marks in imaginary design courses in visual arts education, repetitions of the same subjects, not placing distinctive, creative and interesting studies during lesson have lead to lack of interest of the students on drawing. The idea that drawing can even be learned in adulthood and they can increase their self confidence and create new works, instead of the idea that they have not ability to draw from the birth is imposed on students, they could be successful.

\section{Additionals (Examples of Studies)}

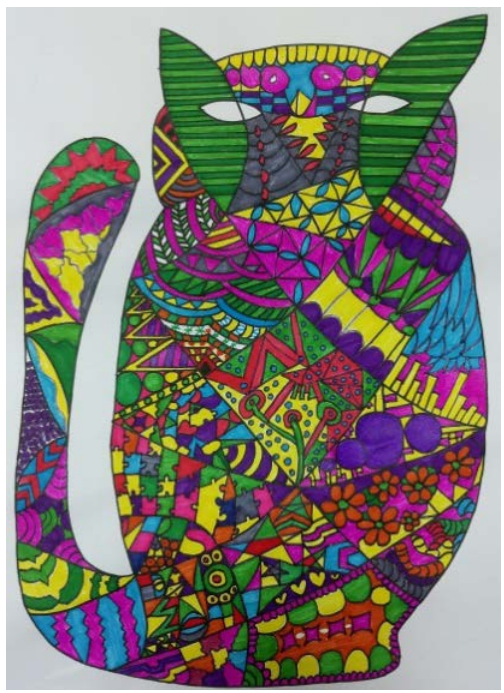

Figure 1. Example of line and color work

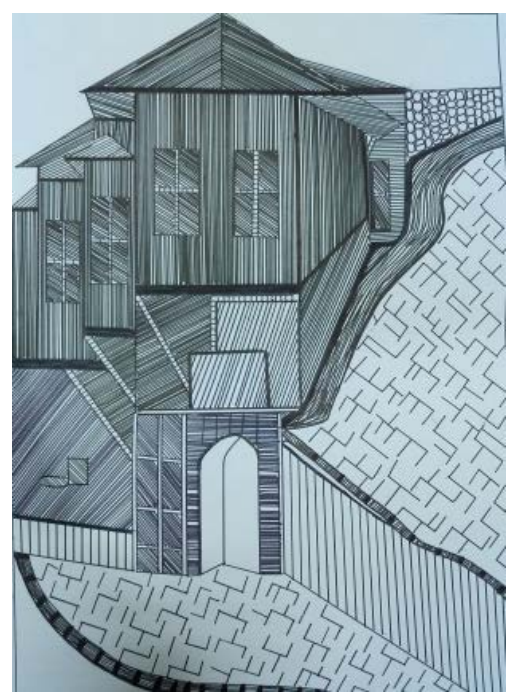

Figure 2. Example of line work

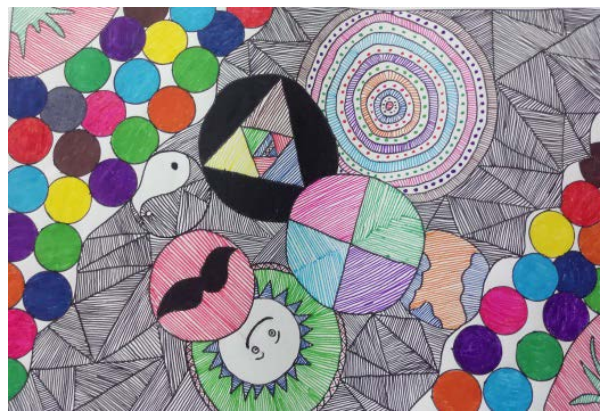

Figure 3. Example of line and color work

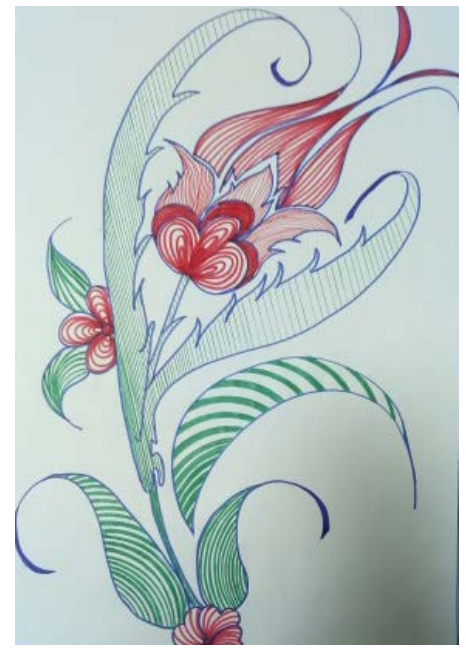

Figure 4. Example of line and color work 


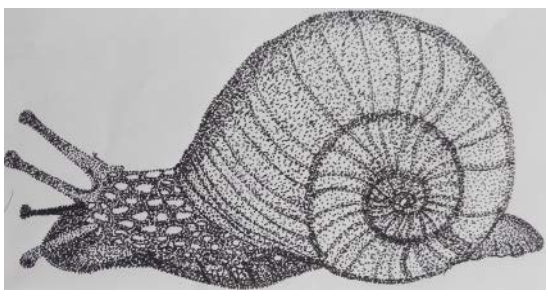

Figure 5. Example of Point work

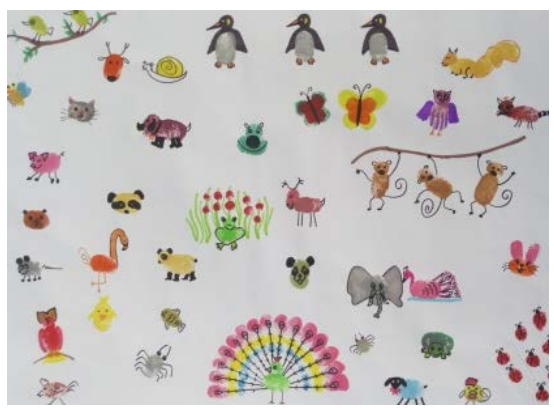

Figure 6. Example of color work

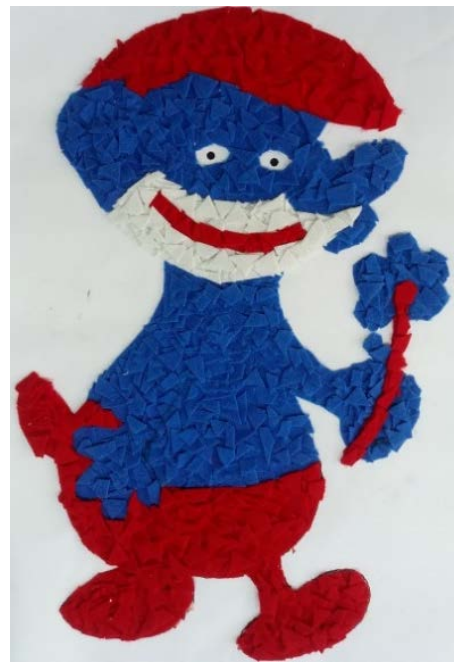

Figure 7. Texture and color study example

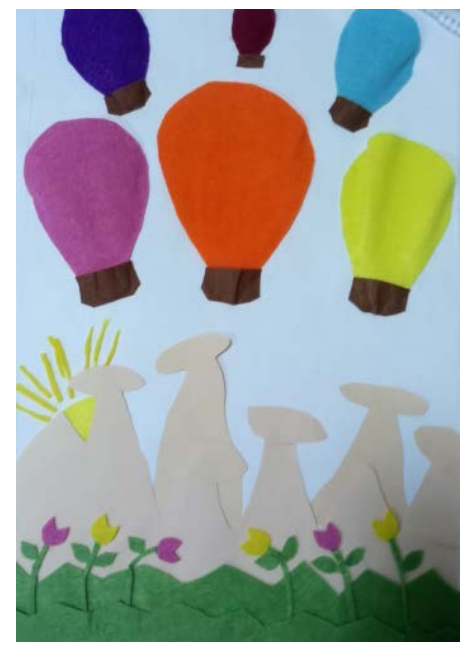

Figure 8. Texture study example

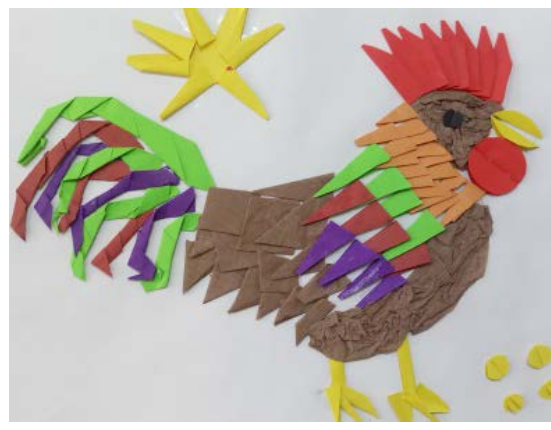

Figure 9. Texture study example

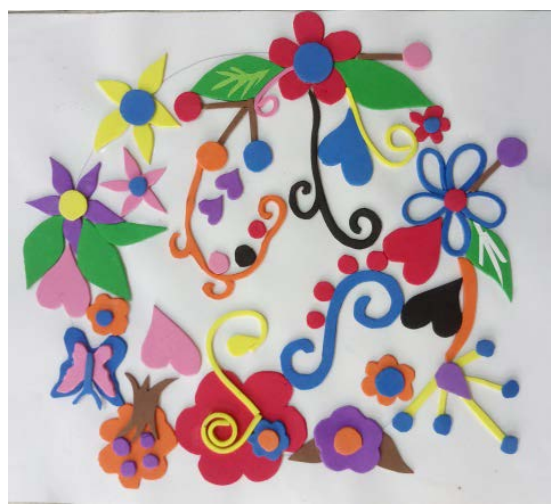

Figure 10. Texture and color study example

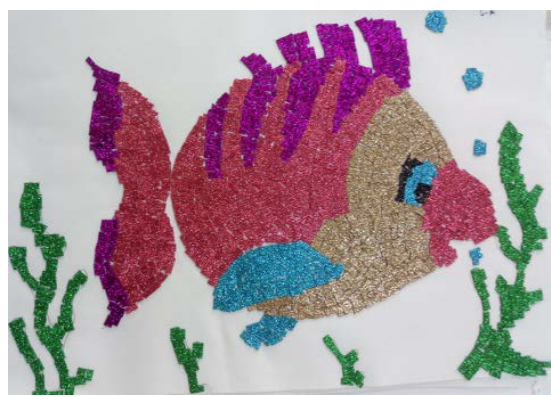

Figure 11. Texture and color study example

\section{REFERENCES}

[1] L. Mercin, Art Education and Visual Arts Teaching (1st Edition). Ankara: Pegem Academy Publications, 2009;

[2] K. Artut, Theories and Methods of Art Education (3rd Edition). Ankara: An1 Publication, 2004; 18

[3] H. Read, Art and Society, Trans. Selçuk Mülayim, Ankara: Umran publications, 1981;

[4] V. Özsoy, Visual Arts Education, Historical and Intellectual Fundamentals of Art Education, Gündüz Education and Publishing: Ankara, 2007;

[5] E. H. Gombrich, The Story of Art, Remzi Bookstore, 2007; 4

[6] A. Ayaydın, Art Education and Visual Arts Teaching (1st Edition). Ankara: Pegem Academy Publications, 2009; 38 
[7] S. A. Cömert, 14 Years of Middle School and Intermediate Level Mentally Disabled Students' Comparison of Line Drawing Skills. İdil Art and Language Magazine Volume 4, Number 15, Winter 2015; 2

[8] S. Tansuğ, Visual Language of Art (3rd Edition). Istanbul: Remzi Kitabevi, 1988; 32

[9] Z. Kehnemuyi, Child's Visual Art Education (3rd Edition). İstanbul: Yap1 Kredi Publications, 2002; 57

[10] S. The Laws of Color and Harmony (4th Edition) İstanbul: İnkilap Kitapevi Publications, 1993; 82

[11] N. Gökaydın, Basic Art Education (1st Edition). Ankara: Ministry of National Education Publications, 2002; 58

[12] Karayağmurlar, B., Özen, D. ve Şahin, N. Açık Öğretim Fakültesi Okul Öncesi Öğretmenliği Lisans Programı Okul Öncesi Resim Öğretimi (1. Bask1). Eskişehir:Anadolu Üniversitesi Yayınları. No: 1419. 2002:8

[13] Kılıçkan, H. ve Kılıçkan H. İlköğretim Ve Ortaöğretim Okulları İçin Okullarda Resim İstanbul: Fil Yayınevi. 1997:15

[14] A.Yıldırım, H. Şimșek, Qualitative Research Methods in Social Sciences (1st Edition) Seçkin Yayıncılık: ANKARA, 2003; 158

[15] N. Karasar, Scientific Research Method: Concepts Principles Techniques (26th Edition), Nobel Publishing House: Ankara, 2014; 27 